IRA-International Journal of Management \&

Social Sciences

ISSN 2455-2267; Vol.14, Issue 02 (February, 2019)

Pg. no. 40-46.

Institute of Research Advances

http://research-advances.org/index.php/RAJMSS

Institute of

\title{
Equalising the Gender: A Study on Women and Transwomen Enterprises in Kerala
}

\author{
Akhila E. ${ }^{1 \#}$ \& Ursula V. A. ${ }^{2}$ \\ ${ }_{1,2}^{1,2}$ Ph.D Research Scholar, Department of Social Work, Pondicherry University, Puducherry - \\ 605014 India.
}

\#corresponding author

Type of Work: Peer Reviewed.

DOl: http://dx.doi.org/10.21013/jmss.v14.n2.p2

\section{How to cite this paper:}

Akhila E., Ursula V. A. (2019). Equalising the Gender: A Study on Women and Transwomen Enterprises in Kerala. IRA-International Journal of Management \& Social Sciences (ISSN 24552267), 14(2), 40-46. doi:http://dx.doi.org/10.21013/jmss.v14.n2.p2

(C) Institute of Research Advances.

(c) $\mathrm{BY}-\mathrm{Nc}$

This work is licensed under a Creative Commons Attribution-Non Commercial 4.0 International License subject to a proper citation to the publication source of the work.

Disclaimer: The scholarly papers as reviewed and published by the Institute of Research Advances (IRA) are the views and opinions of their respective authors and are not the views or opinions of the IRA. The IRA disclaims of any harm or loss caused due to the published content to any party.

Institute of Research Advances is an institutional publisher member of Publishers International Linking Association Inc. (PILA-CrossRef), USA. The institute is an institutional signatory to the Budapest Open Access Initiative. Hungary advocating the open access of scientific and scholarly knowledge. The Institute is a registered content provider under Open Access Initiative Protocol for Metadata Harvesting (OAl-PMH).

The journal is indexed \& included in WorldCat Discovery Service (USA), CrossRef Metadata Search (USA), WorldCat (USA), OCLC (USA), Open J-Gate (India), EZB (Germany) Scilit (Switzerland), Airiti (China), Bielefeld Academic Search Engine (BASE) of Bielefeld University, Germany, PKP Index of Simon Fraser University, Canada. 


\begin{abstract}
The study is focusing on the impact that the entrepreneurship made on the social life of women as well as transwomen in Kerala, India. The Kudumbashree Mission of Kerala, which is a self-help group movement for women in the state is one of the efforts that running successfully since 1998 achieving the gender equality in all the walks of life through women empowerment. Kudumbashree is also showing a model by defining the womanhood in a wider perspective by including the transwomen. It is a novel and path-breaking initiative by Kudumbashree to start micro enterprises for transwomen. The success stories of Kudumbashree women enterprises are model to the country in its role to empower the women. The present study particularly focuses on the impact that the enterprises made on the social life of women as well as transwomen in terms of recognition, reception and reward. The study followed a narrative approach to draw the lived experiences of the participants who selected purposively from the Kozhikode District of Kerala State.
\end{abstract}

Keywords: Gender Equality, Kudumbashree, Transwomen, Women.

\title{
INTRODUCTION
}

The broad term gender, which explains the physical and/or social condition of being male or female is more often used as a synonym for women and mostly linked with inequalities faced by women. The Goal 5 of Sustainable Development Goals (SDG) says about achieving gender equality and empowers all women and girls and also ends all forms of discrimination against all women and girls everywhere. The SDG is on its way to accomplish its goals for people, planet and prosperity by 2030 .

Self-help groups in India played a greater role in women empowerment in terms of economical, political and social spheres. It also helped the Indian women to form up groups and start-up enterprises. The idea of Self-help groups is conceived by the State Poverty Eradication Mission of Government of Kerala and the programme named Kudumbashree is launched in the year 1998. Kudumbashree operates through neighbourhood collectives.

To gear up the process of economic development, Kudumbashree is supporting the establishment of Micro enterprises by women. There are 26,295 micro enterprises functioning in the state both in the service and manufacturing sector. Kudumbashree provides credit and guidance for the establishment of micro-enterprises It made a huge difference in the economical, political and social status of women, especially the rural poor women. A lot of micro enterprises have been formed and working successfully under the Kudumbashree project in Kerala. Kudumbashree is also showing a model by defining the womanhood in a wider perspective by including the transwomen also. It is a novel and path-breaking initiative by Kudumbashree to start micro enterprises for transwomen.

Micro-enterprises are employment-generating sectors at low-cost capital. Micro- and small enterprises are accepted as the engines of sustained economic growth for promoting economic development. Micro-finance activities play an important role in the empowerment of women. (Arul Paramanandam \& Packirisamy, 2015). In accordance with the provision of Micro, Small \& Medium Enterprises Development (MSMED) Act, 2006 Micro Enterprises are the enterprises in which the investment in plant and machinery does not exceed twentyfive lakh rupees. In the case of the service sector, the investment for equipment should not exceed ten lakh Indian Rupees. Although the Kudumbashree project in Kerala gives more importance to the development of women micro enterprises, the transgender policy of Kerala 2015 triggered a change in the state which resulted in the formation of special NHGs for transgenders. Kudumbashree mission helps them for access to all the rights and social security measures so that they can live like any other citizen in the country. Now there are 21 Transgender NHGs in the state which include 274 members and 12 transgender Micro Enterprises working across the state.

The success stories of Kudumbashree women enterprises are model to the country in its role to empower the women. The present study particularly focuses on the impact that the enterprises made on the social life of women as well as transwomen in terms of recognition, reception and reward. The study followed a narrative approach to draw the lived experiences of the participants who selected purposively from the Kozhikode District of Kerala State. 


\section{METHOD}

\section{The objective of the study}

- To understand the impact of the micro enterprises on the social life of women and transwomen in terms of recognition, reception and reward.

\section{Participants}

The study participants include the members of Kudumbashree Enterprises functioning in the Kozhikode District of Kerala. Kozhikode is one of the three districts, among the 14 districts of Kerala in which the number of micro enterprises is very high (2972). Kudumbashree usually promotes women enterprises and presently they extended their scope to transwomen enterprises also. Hence the study covers the members of both women and transwomen enterprises. The researchers select two individuals who have lived the experience of being in Kudumbashree and convenient to spent considerable time to share their stories. According to Creswell (2000), in narrative research one or two individuals are required rather than using a pool of participants to develop a collective story.

\section{Research Design}

It is an attempt to narrate the lived experiences of the members of Kudumbashree enterprises on how they are minimizing the demarcation between the gender spectrums in woman hood. The study adopted a narrative approach to detail the stories of women and transwomen as the members of Kudumbashree enterprises. The researchers try to capture the details of their life stories within their personal experience and also in their cultural context. In order to organize the story, the study used Three Dimensional Space Model (Clandinin and Connelly, 2000) explaining on temporal, spatial and the personal-social aspects.

\section{Procedure}

In-depth interviews were conducted among participants in which the participants narrate their life stories as Kudumbashree members. The interviews were conducted in a place where the participants are comfortable and audio recorded. The researcher also visited few enterprises, exhibition halls where the Kudumbashree units put stalls and also some of the officials of Kudumbashree Mission to better understand the context. The story told was rewritten unfolding the events and turning points in the life of the participants and tried to describe how individuals construct themselves within an institutional and cultural context.

\section{Ethical Consideration}

The research followed proper ethics during the entire study. The participants were informed about the purpose of the research. An oral consent was given by the participants. Interviews were voluntary and the participants had the right to withdraw their interview at any point. Participants name or any other data of personal identification have not used anywhere in this study. Throughout the research work, all participants were aware of the role of the researchers.

\section{RESULTS}

\section{Narration 1 - SHE}

The morning Sun brightens with the light from the burning firewood of her kitchen. The birds hums and flies for the lovely smell of sambar she cooks. Checking everything is ready to serve for the family she wakes her kids up. By the time her husband and in-laws would wake up. Directing them for having breakfast and keeping the packed lunch for kids, she leaves the home with a food packet. She sits in a bus paying 10 rupees. The bus stops where she finds herself.

"a few months before I can reach here by paying 7 rupees. I had to keep coins for regular travel. Now it is very easy as a single note of 10 rupees serves the purpose." She says and laughs sarcastically on the hike in bus fare.

She transformed herself a lot after joining the group. She now comments on the social issues, shares talks on the common problems, and many times she becomes a thread to solving some issues. The change from discussing 
only kitchen affairs to discussing large social issues had a story of a long tussle. The story is not only hers but it is the story of a group of 'middle-class home makers' who became the change makers of their own life.

\section{Recognizing as a woman}

"I am born in a lower middle-class family and was not that good enough for studies. So like other girls who are poor in their studies, I also get married after my $10^{\text {th }}$ standard education. Not immediately but at the age of 19. As usual, I became the mother of a baby girl a year after our marriage. The family which I got into is also a middle-class family. We were five members and living with the sole income of my husband who is a daily wage earner. I was living a quiet normal life as all house wives recognizing kitchen as my world. No other thoughts never came to my mind so to any of my family members till I join Kudumbashree in the year 2005 and by that time we had one more baby."

She is very much enthusiastic to talk about herself and her transformation from a home maker to a Kudumbashree member. The membership in the Kudumbashree never demeans her identity of a home maker, at the same time, it gave an extra identity of a woman entrepreneur. At the beginning, she was part of a small neighbourhood unit of Kudumbashree which mainly focused on microfinance. That was acceptable by her family since most of the women in the neighbouring household were the members of it and also can borrow money for the immediate needs. But when it comes to joining the enterprise and going for training was not readily acceptable by her family. Going out of the home and working somewhere was beyond the thoughts of everyone around her. Even she was somewhat confused and scared to go out as she was not used to it. Anyway, she managed to come out of it.

Now she is the happiest for the decision to join the Mission. The happiness and satisfaction were obvious in her words and her smiles.

"I got this opportunity because I am a woman and a home maker. I am continuing here because we all are women and home makers. This consideration and work atmosphere gives us the energy to work. I may never be here if there is any man working here. The 'we' feeling that we have can never create in any other work place. We recognize each other as a woman with family responsibility and our work is flexible accordingly."

The feeling of togetherness and comfort she had never made her feel that she left behind her home and came to work. The enterprise is another family to her and for all others. She is so energetic, running around, working and talking. She was saying through her work that 'I am happy because I am a woman and we are.'

\section{Receiving as an individual}

The feeling of 'woman' turned to the feeling as an individual when she starts recognized by her family for her efforts. Before she became the entrepreneur the only question that she was asked by her husband that 'what do you need to cook?' and the kids always ask 'what is there to eat today?'. Her thoughts and actions were narrow down to answer only to these questions. Now everything is changed. She was asked an opinion for every decision that takes at home on family matters. She also has a lot to talk to her family. The acceptance she is getting from her family means a lot to her.

"I feel very happy and also proud whenever my husband asks opinion on something. He even started asking me about taking a day off from his work. It never happened before. Also, one thing should be noted that I never felt dejected even before they started asking me about things. I was normal with the way I am. But the difference is that now I feel more accepted and I also feel that I am an inevitable part of our family."

\section{Rewarding for the effort}

She started to get income from the sale of products that they are manufacturing. The income may sometimes is not stable but still is satisfactory enough to make them financially independent and also to support the family. She now earns an amount not less than rupees 5000 in a month. 
"I was always concerned about the money as we have a sole source of income and it is very meagre. Hence I never prioritize my wishes and needs over our family. But now I can support my family financially. We renovated our home with the income that I gain from here. We can now easily manage the education expenses of the kids, medical expenses of the in-laws and some of my personal needs also."

She smiled by holding her right hand and caressing the gold bangle she is wearing. She is much happy as the way she is now. Her income is not regular because the Nutrimix (Amrutham powder), the product they are manufacturing is not for the sale of any outside source. It is the product initiative by the Government to distribute it to children through ICDS (Integrated Child Development Services). So the natural lag in the Government process and formalities is present here also. The money usually comes once in 4 to 6 months. As she said there is no much difference in getting the money out of the business whether it is nutrimix, pickle manufacturing or upper stitching enterprise. Her firm has a problem with the delay in official formalities but the other firms may have problems with the marketing of product or procuring of raw materials. One or the other problem will be there with every enterprise. They together as a group always managed to move forward. Because they wanted to be in the place which helps them to identify themselves. From her words,

"Nothing is much rewarding than the recognition, acceptance and the happiness we get from our work."

She always mentions 'we' in her talks pointing that 'it is not my story it is our story.'

\section{Narration 2 - sHE}

'Punarjani', which means 'reincarnation' in English, is the name of her Kudumbashree unit. It is consciously chosen as it gives a new dimension to the lives of all the 10 members in this unit. It is a story of a strongminded, beautiful, charming lady who dares to show that 'I am also a woman' to a society where woman is considering lower to man even her birth showed her as a 'male'.

We would like to call her as a woman rather than a transwoman in the way Kudumbashree erases the demarcation between the 'two genders'. Even though in some places we forced to highlight the 'trans' of the gender like in the research studies.

\section{Recognizing as an individual}

She knows about Kudumbashree ever since her mother started going to neighbourhood group meetings. She used to see her mother going out alone only when there is a meeting and she remembers that her mother was so energetic and happier on the days of the meeting. But she never knew what was happening there and why her mother is regularly going for the meetings.

"I noticed that whenever she goes to the meeting she keeps 10 or 20 rupees with her to deposit in the savings. So once I asked how you are going benefited with this very small amount of money. How much could you generate from this 10 rupees savings? Her answer was very vague for me at that time. She said, 'it is not a small 10 rupees, there are so many things attached to it. You cannot understand that.' But now I can feel what she was feeling that time. It is really beyond the words."

The transgender persons have started recognition in the state after commencing the State Policy of Transgenders in 2015. Before that identity of a transgender person is not at all recognized by the Kerala Community. As her family accepted the way she I, for her family was not a problem. Her profession as a dance trainer also gave slight consideration of her femininity when she was recognized as a man. She also mentions that she rarely use public transport or public utilities to avoid the awkward attitude of people towards her. She was not brave enough to wear a saree or express her femininity in public. She used to wear Jeans and T-shirts whenever she goes out which gives at least some satisfaction that it considered as a unisex dress. The change that transgender policy could bring is evident. Even the Kudumbashree started to include transwomen after the Policy came into force in 2017. Till then transgender persons are not even considered as human being by the people. In her words, 
"Kudumbashree is the one that gave us the recognition. Not in my case, but most of us were not even come out by fearing the public. Kudumbashree gave the support and courage to come out with our identity in a public vicinity. And that works."

\section{Receiving as a woman}

"The chechis of the Kudumbashree consider us as their younger sisters. They have been in Kudumbashree for a long. So they used to guide us for the functioning of the unit. I started feeling that I am also a woman like them only after joining the Kudumbashree. The feeling is really awesome. They never gave a chance to feel me that I am different from them in some or other ways. The support offered by the officials and the other members is enormous."

The happiness that she expressed in her words reflects the acceptance she receives as a woman. Kudumbashree is historically marked for its outstanding contribution to the empowerment of women and they are the first one accepting transwoman at par with the woman. Unlike other initiatives, Kudumbashree gave the opportunity for her to show that I am also not less than a woman and we are women need not be separated. She says that the people will still sometimes stares at her with curiosity whenever go for the exhibitions of Kudumbashree stalls. But never behaved indifferently, accepting us as Kudumbashree members. This kind of public presence made the common man also accepting her as a complete woman.

She also concerns about some of the transwomen that they still think that Kudumbashree is only for 'women'. They themselves are self-discriminating from the mainstream. She has a plan to provide an awareness class to others who are hesitant to come out on Kudumbashree.

\section{Rewarding for the effort}

Along with the recognition, reward in the form of money also matters for someone who is struggling for a livelihood. From an income that could never match with expenses to an income that can save after the expenses is a big difference. The difference can be created by the membership in the group. Even the enterprise is in the initiation stage, the income could be generated from the exhibitions and cafes. She now set aside her job as a dance trainer to work for the Kudumbashree on a full-time basis. She is in a leadership position, planning and implementing more accepted and feasible ways to equip with the capacities. She is confident to say that soon the Kudumbashree will have more innovative enterprises with more women.

\section{DISCUSSION}

The stories talk about a miserable past, wonderful present and a hopeful future of two women who are in their late $30 \mathrm{~s}$ and can match with the others in the group they belong to. They belong to the middle-class families following a socially constructed normal life without any individual recognition. In the Kerala society, the identity of a middle class sits at home woman or even a working woman always attached with the family. The Kudumbashree break those norms of the society giving them a separate identity through a group. The enterprises, the place where they work, the place which gave them recognition, the place which made them happy and the place they are so attached with sometimes more than their family. The happiness, worries, troubles, jokes, food, work everything they share in that place. A late night work also never bother if they are at their favourite place. The charm we can find among these ladies is rarely found among the woman of the same age who never experienced the warmth of this group.

The warmth extends to the persons who were never recognized as women by society. The experience of 'sisterly' feeling is the greatest reward Kudumbashree extends to the transwoman. It is the stepping stone towards the wide recognition as an individual and as a woman who is capable as others. The self-esteem and confidence are visible while talking with her. As Tajfel and Turner (1978) theorize, "individual define their own identities with regard to social groups and that such identifications work to protect and bolster selfidentity." The statement stands true in these two stories. Their identity became strong when they started working with the group. The group membership strengthens their woman identity hence lead to better selfconcept and self-esteem. Turner and his colleagues' (1987) theory claims that identity is shaped by selfcategorization; by people looking at social categories, and deciding whether or not they are in a category. If they consider themselves a member of a category, that category becomes the part of their identity. 


\section{CONCLUSION}

Using a narrative approach of research, the present study focused on the impact that Kudumbashree micro enterprises made on the social life of women as well as transwomen in terms of recognition, reception and reward. The study attempted to narrate the lived experiences of the members of Kudumbashree enterprises on how they are minimizing the demarcation between the gender spectrums in woman hood. The stories of both women and transwomen talk about a miserable past, wonderful present and a hopeful future. They belong to the middle-class families following a socially constructed normal life without any individual recognition. The enterprises, the place where they work, are the place which gave them recognition, happiness, reception from the family and society and life satisfaction. It is the work place they are so attached with sometimes more than their family. The happiness, worries, troubles, jokes, food, work everything they share in that place. The charm we can find among these ladies is rarely found among the woman of the same age who never experienced the warmth of this group. They feel greater flexibility in the work and at the same time they feel responsible as well as committed. The warmth extends to the persons who were never recognized as women by society. The experience of 'sisterly' feeling is the greatest reward Kudumbashree extends to the transwoman. It is the stepping stone towards the wide recognition as an individual and as a woman who is capable as others. The selfesteem and confidence are visible and promoting entrepreneurship of women and transgender people in a wider range can equalize the gender disparities existing in the world for decades.

\section{REFERENCES}

[1]. Arul Paramanandam, D., \& Packirisamy, P. (2015). An empirical study on the impact of micro enterprises on women empowerment. Journal of Enterprising Communities: People and Places in the Global Economy, 9(4), 298-314. https://doi.org/10.1108/JEC-08-2014-0017

[2]. Clandinin, D, J., \& Connelly, F, M. (2000) Narrative inquiry: experience and story in qualitative research. San Francisco: Jossey-Bass Publishers

[3]. Creswell, W. John. (2007). Qualitative Inquiry and Research Design; Choosing among five approaches. Thousand Oaks: Sage

[4]. Tajfel, H., \& Turner, J. C. (1979). An integrative theory of inter-group conflict. In W. G. Austin \& S. Worchel(Eds.), The social psychology of inter-group relations (pp. 33-47). Monterey, CA: Brooks/Cole.

[5]. Turner, J, C. Hogg, M, A. Oakes, P, J. Recher, S, D. and Wetherell, M. 1987. Rediscovering the social group: A self-Categorization theory. Oxford: Basil Blackwell.

[6]. Ministry of Micro, Small \& Medium Enterprises. (2015). What are Micro, Small \& Medium Enterprises? Retrieved March 10, 2018, from Development Commissioner (MSME) Ministry of Micro, Small \& Medium Enterprises: http://dcmsme.gov.in/ssiindia/defination_msme.htm

[7]. Kudumbashree. (2018).Retrieved on July 20, 2018 from Kudumbashree Newsletter http://www.kudumbashree.org/storage//files/ypfsu_kudumbashreenewsletter18july2018.pdf

[8]. Kudumbashree. (2018). Retrieved on July 20, 2018 from kudumbashree.org http://www.kudumbashree.org/.

[9]. Definition of gender.

Retrieved on July 20, 2018, from https://www.collinsdictionary.com/dictionary/english/gender 